1994

\title{
Gender Equality, Family Law and Access to Justice
}

Mary Jane Mossman

Osgoode Hall Law School of York University, mjmossman@osgoode.yorku.ca

Source Publication:

International Journal of Law and the Family. Volume 8, Issue 3 (1994), p. 357-373.

Follow this and additional works at: https://digitalcommons.osgoode.yorku.ca/scholarly_works (c) (1) $(9)$

This work is licensed under a Creative Commons Attribution-Noncommercial-No Derivative Works 4.0 License.

\section{Recommended Citation}

Mossman, Mary Jane. "Gender Equality, Family Law and Access to Justice." International Journal of Law and the Family 8.3 (1994): 357-373.

This Article is brought to you for free and open access by the Faculty Scholarship at Osgoode Digital Commons. It has been accepted for inclusion in Articles \& Book Chapters by an authorized administrator of Osgoode Digital Commons. 


\title{
GENDER EQUALITY, FAMILY LAW AND A CCESS TO JUSTI CE
}

\author{
MARY JANE MOSSMAN*
}

A BSTR A CT

This article focuses on recent issues in Canada concerning (in)equality of access to justice in family law matters on the basis of gender. Citing a recent report of the Canadian Bar Association's Task Force on Gender Equality which identified problems, especially in legal aid funding, for family law clients, the paper suggests that the Task Force's conclusions about gender inequality in legally- aided family law matters are closely related to other issues about gender and legal aid: the ongoing controversy about the appropriateness of student legal aid clinics which have adopted policies of representation for battered women, but not for alleged batterers; and a current issue in Ontario about the need for a 'woman only' family law clinic service. The article suggests that these issues need to be examined in light of basic principles about legal aid funding: the reality of 'neutrality' in gender-neutral categories of entitlement; the 'public/ private' dichotomy created by well-funded legal aid services for criminal law matters ('public') and inadequate funding for family law matters ('private'); and the impact of constitutional guarantees of equality in the Canadian Charter of Rights and Freedoms. As well, the paper suggests a need for 'revisioning' access to justice which promotes gender equality. While the paper focuses on recent issues in Canada, it illustrates approaches to problems of gender and access to justice which are 
international, particularly in the context of down- turns in national and international economies.

\section{IN TR ODU CTION}

The low status of family law pervades all facets of our justice system and is reflected in a lack of public resources devoted to resolving conflicts in this critical area. This low status is rooted in the gender-related approach of our legal system ... Flowing from the gender bias in our justice system is the devaluation of family matters as being essentially private and therefore outside the realm of the 'real law'. ${ }^{1}$

These assertions about gender inequality in family law matters were made in a 1993 report sponsored by the Canadian Bar Association. The main focus of the CBA report was an assessment of gender equality in the legal profession in Canada, with recommendations for 'fundamental change'. ${ }^{2}$ The report reviewed the problem of gender inequality in the legal profession in a variety of contexts: law schools and bar admission programmes; private practice firms, government legal departments and corporate settings; courts and tribunals; and law societies and the Canadian Bar Association itself. ${ }^{3}$ Having identified the nature and scale of the problems of gender inequality, the report set out a framework for understanding equality and discrimination in Canadian $\mathrm{law}^{4}$ and the factors which should motivate the legal profession to change. According to the report, change is mandated because: 
- gender equality is a fundamental legal norm;

- gender equality is a matter of ethics and justice;

- gender equality in the legal profession represents enlightened selfinterest and accountability within a self-regulating profession; and - gender equality for lawyers is in the public interest. ${ }^{5}$

Significantly, in the context of this report devoted to gender equality in the legal profession, the Task Force devoted a full chapter to assessing the practice of family law in Canada as 'a case study'. ${ }^{6}$ Commenting on the number of submissions received from judges, law teachers and practitioners (both in private practice firms and in government) expressing concerns about the practice of family law, the Task Force report explained that its review of family law also permitted an assessment of the degree to which the justice system 'reflected the priorities and values of Canadian society'. Thus, the report noted the oft expressed commitments of federal and provincial governments in Canada sup- porting family life, legislative enactments designed to protect family members, and legal aid schemes created to ensure access to justice in family matters. For the Task Force, the case study of family law was an opportunity to ask searching questions about the reality of these commitments:

Are these endeavours backed up by practical commitments? Are the lofty phrases of our legislators reflected in the concrete experiences of our family lawyers and litigants? In reviewing the evidence about the practice of family 
law in Canada, the Task Force found that the reality fell far short of our aspirations and our ideals. Lawyers struggling to provide justice to litigants in this area received little support despite verbal assurances from many levels of government. In the cynical words of one female lawyer, governments provide 'all possible aid short of actual help'. ${ }^{7}$

Thus, according to the Task Force report, the family law context and the situation of female lawyers in this area of practice represented 'a good case study of the impact of gender inequality on the justice

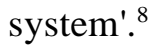

The report's case study on family law identified a number of features which contribute to the disparity between law's stated commitments to family matters and the reality of family law in practice. Central to the problem, according to the report, is the lack of resources available in family law matters. This scarcity of resources is evident in the shortage of vital financial and judicial resources in the justice system for family law dispute resolution, as well as in the absence of sufficient legal aid resources for family law clients. As well, the relatively low status accorded to the practice of family law limits the career options of family lawyers, a disproportionate number of whom are women lawyers in Canada.

In this way, the report suggests that the gender inequality of women in the legal profession intersects with the gender inequity of the justice system in family law; although women who practise as family lawyers may be relatively better-paid than their female clients, their 
circumstances are, relative to men who are lawyers, frequently unsatisfactory. ${ }^{9}$ As the report explained, 'it is very difficult [for lawyers practising family law] to be in a position where partners feel you are billing far too little, and clients feel you are billing far too much', ${ }^{10}$ and where 'negative comments and outright contempt' make law practice unpleasant. Since a disproportionately high number of Canadian family lawyers are women, gender inequality in family law matters contributes directly to gender inequality within the legal profession.

The CBA report's 'case study' on family law thus raises important equality issues for both family law practitioners and the legal profession as a whole. For those involved in family law practice, the report reinforces Michael Freeman's assertion that 'lawyers who remain technicians cannot contribute to the ... debate currently raging about the family'. ${ }^{11}$ For the legal profession more generally, the issues also raise profound questions about the administration of justice, questions which are increasingly being raised in Canada in the context of challenges about legal aid funding in family law matters. As needs for legal aid funding have intensified on one hand, and governmental resources have declined in the current economic circumstances in Canada on the other, ${ }^{12}$ challenges about the allocation of scarce legal aid resources (especially for women claimants involved in family law disputes) have become more frequent and more bitterly debated 
among lawyers. In this context, the CBA report's case study on family law presents a challenge to the legal profession as a whole.

This paper reviews the report's consideration of legal aid funding in family law and its recommendations, having regard to some recent challenges in Ontario concerning gendered legal aid services in the family law context. It addresses these issues about gender equality in legal aid services by rethinking some of the fundamental assumptions of legal aid services in Canada, and the ways in which such assumptions may reinforce, rather than eliminate, gender inequality for legal aid claimants. While the focus of the analysis is family law and legal aid services in the Canadian context, the issues are similar for a number of other jurisdictions where recent governmental policies (as in the United Kingdom) may exacerbate the problem of gender and unequal access to justice in relation to family law. ${ }^{13}$

\section{Gender equality CHALlenges to LEgAL Aid SERVices IN FAMILY LAW}

The CBA report characterized inadequate resources in relation to legal aid services as 'systemic injustice' for family law clients (and their lawyers). According to the report, the Task Force received an 'outpouring of frustration' in submissions about the funding of family legal aid in general and the 'gross discrepancy between the greater resources allocated to criminal legal aid and the much smaller amount available 
for family legal aid'. ${ }^{14}$ Concerns were expressed about tariff levels for family law cases, the absence of funding for special disbursements (including expert witnesses), ${ }^{15}$ and the emphasis in family law tariffs on litigation and court appearances rather than research, mediation and negotiation, even if the latter were successful. ${ }^{16}$

Moreover, many lawyers asserted that 'they simply could not afford to take legal aid certificates' or that their firms would not permit them to do so. According to the report, the Task Force heard an 'oft-repeated remark' from family lawyers that it was cheaper for family lawyers to work pro bono than on legal aid funding, thus avoiding the paperwork required by legal aid programmes. More pointedly, family lawyers drew the Task Force's attention to the disparity in resources available to legal aid clients for criminal law matters, by contrast with those for family law clients:

Why does criminal legal aid pay so very well financially while doing family legal aid is a positive drain on your bank account? In British Columbia one day in criminal court pays $\$ 1600.00$ whereas one day in family court pays $\$ 400.00$. This seems to be a form of systemic discrimination calculated to lure good family lawyers into lucrative criminal practice. Where are our 'family values'? There seems to be an ironic contrast between the verbal focus on family values and the tangible support given to criminal matters. ${ }^{17}$

Responding to these concerns, the Task Force recommended that federal and provincial Governments 'ensure that adequate legal aid funding for 
family law cases' be guaranteed across Canada and that the federal Government 'establish a national civil legal aid tariff' ${ }^{18}$

As the Task Force report noted, its review of family law represented 'only a beginning'. Moreover, its recommendations need to be considered in light of evolving constitutional jurisprudence about equality in Canada, ${ }^{19}$ a context in which claims have been defined by the Supreme

Court of Canada on the basis of not just 'formal' but also 'substantive' equality goals for those who are most disadvantaged in Canadian society 20 Thus, while the report's recommendations concerning greater levels of funding in family law cases are clearly desirable, a more probing analysis may be needed to accomplish these objectives effectively. This conclusion is reinforced, moreover, by taking account of recent disputes about legal aid services for women seeking assistance in the context of family violence.

The best-known of these disputes involved the decision of a student legal aid clinic at the University of Ottawa to provide legal assistance to women who had experienced violence from family partners, and to deny service to alleged male batterers in cases of domestic violence. As Jennie Abell has argued, the controversy about this decision raised significant philosophical and political issues about equality in the legal process, although the form of the debate which resulted from the clinic's decision generally failed to address them, focusing instead on issues 
about decision-making powers within the profession and on process and procedures. ${ }^{21}$ Although some of the 'facts' of the dispute remain hotly contested, it seems clear that there was an agreement in principle that the clinic would not simply turn away male batterers seeking legal advice and representation; instead, the clinic seems to have intended to refer such applicants to the local legal aid programme for assistance, and it is at least arguable that they would have received representation from lawyers on the basis of legal aid certificates, or at the very least duty counsel services. ${ }^{22}$

Whether or not the clinic's referral policy was ever fully delineated or effectively implemented, however, the local Bar (and especially members of the criminal defence Bar) immediately expressed outrage about the decision, calling for the suspension of governmental funding of the student legal aid clinic and then laying a formal complaint, based on sex discrimination, with Ontario's Law Society in 1990. ${ }^{23}$ Eventually, a formal hearing was conducted and various efforts to achieve compromise through negotiation occurred, although the issue has continued to resurface in other contexts.

Especially for the Law Society, these issues of gender and legal aid services remain controversial, and proposals to establish specialized legal aid services for women continue to meet criticisms based on sex discrimination. Thus, in the fall of 1993, the Law Society rejected a governmental proposal to establish a women-only family law clinic, once 
again on the basis that it would be 'discriminatory'. According to press reports of the decision, the Law Society objected to the creation of such a clinic on the grounds that no case had been established showing that a clinic 'offering these broad services is driven by an access need peculiar to women'. ${ }^{24}$ Such comments suggest that the issue about women's access to legal aid services in family law, especially in cases of domestic violence, remains somewhat misunderstood as well as seriously con-

tested at the present time. ${ }^{25}$

According to Abell, the debate about the policy adopted by the Ottawa student legal aid clinic showed that those opposed to the decision failed to understand the Supreme Court's decision about equal- ity in 1989 in Andrews, and the need to take account of substantive inequality based on societal disadvantage, not just the 'sameness' standard of formal equality: 26

Detractors of the policy charged that it was discriminatory, simply because the clinic proposed to treat men differently from women. Their argument ignores the contextualized legal meaning of equality elaborated in recent decisions of the Supreme Court of Canada. Thus, it is problematic even at the level of strict legal analysis. [According to Andrews], not every distinction between individuals and groups will give rise to a violation of section 15 of the Charter. Instead, it is clear that the promotion of equality contemplated by that section goes beyond the mere elimination of distinctions in treatment to a 
consideration of situation and impact. ${ }^{27}$

In light of the Supreme Court jurisprudence, it was thus possible to see the student clinic's policy as one which 'adverted to the special needs of women in dealing with the legal system, the serious social problem of violence against women, and the fact that many women have gone without representation in dealing with the legal consequences of violence'.28 Moreover, for the clinic's services to be effective in this role, the students saw their policy as necessary 'both to avoid potential conflicts

of interest and to enhance their credibility in women's eyes'. ${ }^{29}$

Thus, these continuing challenges to the development of legal aid services expressly designed to meet women's needs in family matters raise important and controversial issues about the meaning of gender - equality in the Canadian legal aid system. Moreover, while the recommendations of the $\mathrm{CBA}$ report affirm the need for action in relation to more comprehensive legal aid services in family law, these recent controversies about legal aid services for women clearly demonstrate that fundamental issues remain contested among members of the legal profession. Since these issues also continue to impede reform efforts designed to respond more effectively to the needs of women claimants for legal aid services in family law matters, a more fundamental assessment of gender equality and access to justice in the family law context is needed. 
3. GENDER EQUALITY, FAMILY LAW AND ACCESS T

O JUSTICE: FUNDAMENTAL PRINCIPLES

As Deborah Rhode has suggested in relation to issues of justice and gender in the United States, 'significant progress toward gender equality

will require ... substantial changes in our legal paradigms and social priorities' ${ }^{30}$ Similarly, in thinking about the issue of legal aid services for women in family law cases in Canada, it is necessary to rethink some fundamental principles, both about legal aid services and about gender equality in the family law context. This paper explores some of these more fundamental principles by challenging the 'neutrality' of current categories of entitlement to legal aid services and by demonstrating how they replicate the public/private dichotomy so frequently used to deny legal equality to women. As well, the paper focuses on equality jurisprudence in Canada, especially in relation to gender issues, and raises questions about its potential for challenging current arrangements for legal aid services. In doing so, the paper also envisages the need to transform law and legal processes so as to achieve justice for women in the family law context, an objective characterized by Rhode as one of 'broadening our aspirations to justice'. ${ }^{31}$

\section{A. Neutrality}


Legal aid services are provided in Canada (as elsewhere) on the basis of 'categorical entitlement'; that is, defined categories of legal services are offered, either on a mandatory or discretionary basis, to those who meet the programme's eligibility guidelines. ${ }^{32}$ On its face, a 'categorical entitlement' programme is gender neutral and non-discriminatory, merely defining the categories of legal services to which eligible claimants are entitled. For those involved in assessing the law's responsiveness to women's claims, however, such gender neutral categories may be inherently suspect as 'artificial classifications', because women were not involved in defining them, because women's interests may have been less valued or understood in the process of defining categories, or because legal aid programmes have replicated categories from the legal system which have not taken women's experiences into account. ${ }^{33}$ For these reasons, a categorical scheme of entitlement to legal aid services may mean that, in practice, women's needs are less well served than those of men.

There is some data that the use of these 'neutral' categories for entitlement to legal aid services in Canada has resulted in a disproportionate amount of legal aid services for male rather than female claimants. Thus, for example, a 1992 report in Ontario concluded that 'the legal aid budget [in Ontario] is unequally distributed and favours men's legal problems, primarily criminal, over women's legal problems, primarily matrimonial'.$^{34}$ This evidence that 
men are more often entitled to legal aid services, by contrast with women, raises important questions about the substantive 'neutrality' of legal aid guidelines in practice, ${ }^{35}$ suggesting that gender-neutral language may, in fact, 'mask' hidden and gendered preferences for those legal aid services more frequently required by men. Moreover, especially in a context of diminishing state

resources for legal aid services, statutory distinctions between services which are 'mandatory' and those which are regarded as 'discretionary' (distinctions which may also be phrased in gender neutral language) may result in practice in disproportionate resources for men who are legal aid claimants.

In this context, moreover, the significant amount of data in Canada about the relative poverty of women, by contrast with men, creates an urgent need to question the substantive 'neutrality' of legal aid services which are provided less frequently in practice to women claimants. ${ }^{36}$ Indeed, the disproportionate amount of poverty among women, by contrast with men, suggests that gender-neutral categories of entitlement may confirm, as Martha Fineman has suggested, that 'what is is as "biased" as that which challenges it'. ${ }^{37}$ Such an assertion is similarly reflected in Richard Abel's conclusion that serious scholarship about legal aid services must take account of its 'inherently political nature'. ${ }^{38}$ Thus, in the context of women's greater relative poverty, 'neutral' categories of entitlement to legal aid services must be 
assessed in terms of their effects in practice (their substantive results), not simply on the basis of their use of (fonnal) gender neutral language.

\section{B. The Public/Private Dichotomy}

Particularly because of diminishing governmental resources for legal aid services in Canada in recent years, there has been a trend in the allocation of funds to recognize a priority for legal aid services for accused persons charged with criminal offences. Such a priority for legal aid services in criminal law matters has been defended on the basis of philosophical arguments about the need to ensure adequate representation for an individual accused, having regard to the seriousness of such matters and the (theoretically) unlimited resources of the State in adversarial proceedings. However, these philosophical arguments need to be carefully scrutinized, particularly since they result in disproportionate funding for legal aid services in criminal law matters (the 'public'), thereby diminishing resources available for family law (the 'private'). Thus, the preference for legal aid services in criminal law matters may reaffirm the disadvantages for women of the public/private dichotomy. ${ }^{39}$ Historically, the need to provide indigent accused with representation in criminal law matters was never the sole justification for the introduction of provincial legal aid programmes in

Canada in the 1960s and 1970s. The report recommending the creation of the Ontario Legal Aid Plan in 1965, for example, expressed the view that there was no reason to exclude family law matters from legal aid 
entitlement: 'In the contemplation of the law of Ontario, [criminal law and family law matters] are equal ... Any legal aid system which intends to ensure the advancement of the protection of the legal rights of the needy must surely include matrimonial causes'. ${ }^{40}$ Thus, although the factual basis for these assertions is unclear (what information was available about the needs of poor women for legal aid services, by contrast with the needs of poor men?), governmental policy about legal aid services recognized at the outset a commitment to family law services for legal aid clients, as well as in relation to those charged with criminal offences. Significantly, this early commitment has been eroded, not by policy changes per se, but rather by the demands of

'fiscal federalism' in Canada. Thus, the preference for legal aid services in criminal law matters has resulted from the preferential federal funding available for criminal law services, a subject within the jurisdiction of the federal government. ${ }^{41}$ In this context, it is arguable that the current emphasis on legal aid services in criminal law matters results more directly from the realities of federal- provincial relations to a much greater extent than from philosophical values. Moreover, closer scrutiny of the claim that the current priority for legal aid services in criminal law matters is fully justified in terms of important philosophical values also reveals some difficulties from the perspective of gender equality goals. The justification for disproportionate legal aid resources being allocated to those charged with criminal 
offences is that an accused person faces a disparity of legal resources where the state is the other party in adversarial proceedings, and that the possible consequences of the proceedings are severe, including imprisonment. These claims are, of course, important; the issue is whether their impact is gender neutral.

In relation to the first claim, that the accused faces a disparity of resources, it is important to note that legal aid services accord priority to persons accused of criminal offences even though claimants in other legal proceedings may also face the disparity of the State's resources: for example, psychiatric patients in commital proceedings, refugee claimants in status hearings, and parents in child protection proceedings. In each of these cases, parties face the disparity of resources of the State, and they face similarly severe consequences, including loss of liberty in the form of indeterminate commital for psychiatric patients, deportation for refugee claimants, and loss of liberty for children removed from the care of their parents. Thus, for these claimants, as for accused persons, there are both disparities of resources and serious consequences. Yet, the priority for legal aid services accorded to indigent accused does not extend to legal aid services in these other situations so easily.

Such an analysis permits us to probe more deeply the neutrality of a legal aid system which accords priority to those accused of criminal offences, disproportionately men in Canadian society, while 
simultaneously limiting claims by psychiatric patients, refugees, or parents, at least half of whom (or more) may be women. Such a conclusion might at least suggest a need to extend legal aid services to all those involved

in legal proceedings in which the State is a party (and there is a consequential disparity of resources) and where the consequences are serious for the individual litigant in terms of loss of liberty or livelihood. Even more significantly, such an analysis suggests a need to examine the underlying values attached to the consequences of criminal law and family law matters: what are the unstated values of a society which regards the consequences of possible imprisonment for an accused charged with a property offence as more significant than the loss of custody of one's children in protection proceedings? Is the law's traditional division between public and private masking a gendered allocation of legal aid funding?

Moreover, from the perspective of family law disputes, the law's recognition of the need for legal aid services for those accused of criminal offences, on the basis of the disparity of legal resources of the accused and the State, suggests a need for legal aid programmes to take more seriously the disparity of resources of many women, by contrast with their male partners, in family law disputes. Why do legal aid programmes readily accept the arguments about the disparity of 
resources (between an accused person and the State) as the basis for defining entitlement for criminal legal aid services, but systematically deny the significance of such disparities in the context of legal aid services in family law? In thinking about this issue, moreover, it is important to consider whether the disparity of resources in the criminal justice con- text is as real in practice as in theory especially in a context where court congestion, backlogs of cases, and overworked court officials (including prosecutors) may not be as formidable in reality as the philosophical justification suggests. By contrast, a woman in a family law dispute may have to face her affluent husband's well-prepared and well-paid private practice lawyer. Such an analysis suggests that women in family law cases may have needs which, in practice, are just as great in terms of disparate levels of resources as those of men accused of criminal offences. Even in the context of the criminal justice system, data suggests a lack of equality for men and women in terms of access to legal aid services because women may commit different crimes, by contrast with men, $4^{2}$ and because they may be treated somewhat differently by the criminal justice system. ${ }^{43}$ Thus, even women accused of criminal offences may not benefit from the priority accorded to criminal law matters by legal aid services, at least not to the same extent as men. Moreover, in the context of widespread male violence in Canadian society, gender inequality is reinforced by the priority accorded to legal aid representation for those accused of 
criminal offences (including assault), rather than for those who are the victims of violence. Since most accused persons are men and their victims are, most often, women, violence in the 'private' sphere results in legal aid representation for those who must answer in the 'public' sphere, while women's claims for representation (and protection) remain 'private'. Such an outcome suggests the law's complicity in the public/private dichotomy, a dichotomy which also reinforces differential and gendered power relationships in the family.

\section{Equality}

North American jurisprudence about entrenched constitutional guarantees of sex equality have been dominated until recently by ideas of sameness and difference in relation to men and women. According to some American theorists, women's claims to enjoy benefits and advantages traditionally enjoyed by men depend on assertions that women are similarly situated to men (at least in all relevant respects). ${ }^{44}$ By contrast, others have asserted that equality claims must take account of differences between women and men, differences such as those associated with reproduction (and perhaps some aspects of family roles) which mandate differing needs for women, by contrast with men. ${ }^{45}$ Yet, as has been noted, the problem of an approach to equality which focuses on either sameness or difference is that they both reinforce men as the standard to which women are compared. Thus, whether women are regarded as the same as men, or 
different from them, the standard of comparison is gendered.

Especially after the entrenchment of constitutional guarantees of sex equality in the Canadian Charter of Rights and Freedoms, Supreme Court jurisprudence in Canada has adopted approaches to equality analysis which recognize the limits of 'sameness' equality, and thus take account of issues of power differentials and relative disadvantage for defined groups in Canadian society. For purposes of this analysis of entitlement to legal aid services, the decisions of the Canadian Supreme Court are important in two ways. One is the Court's acceptance of a general approach to equality analysis which focuses on substantive outcomes for equality analysis and not just formal ideas about equality. In decisions of the Court about the systemic nature of pregnancy dis- crimination (Brooks v Canada Sofeway Ltd) ${ }^{46}$ and in relation to sexual harassment of women in employment Uanzen v Plary Enterprises Ltd), ${ }^{47}$ for example, the Court accepted concepts of equality and discrimination which recognized gendered societal arrangements and the ways in which they created disadvantages for women. Similarly, in Action Travail des Femmes $\mathrm{v} C N R,{ }^{48}$ the Court recognized the idea of systemic inequality on the basis of sex in a claim which challenged the expectations of men and women about 'non-traditional' work; and which mandated affirmative action remedies. Moreover, in $R \mathrm{v}$ Lavallee, ${ }^{49}$ the Court took into account expressly the differences in a woman's experiences of violence in intimate relationships in recognizing 
the need for expert evidence to establish her sense of 'harm' in relation to the traditional view of the defence of self-defence. Cases such as these arguably demonstrate that Canadian courts have increasingly taken (some) account of the impact of gendered experiences in their equality analyses, especially in the interpretation of Charter guarantees. In this way, there is Supreme Court of Canada authority for an interpretation of equality which goes beyond formal equality guarantees to recognize more substantive needs to accomplish gender equality in practice.

The approach in these decisions is consistent with the Supreme Court's decision in Andrews, where the Court eschewed a 'sameness' approach for one which recognized the need to take account of the idea of relative 'disadvantage' within Canadian society. In such a context, the substantive inequality of legal aid services which fail to respond to women's needs as well as those of men may be inconsistent with constitutionally entrenched equality guarantees. In this way, the Court's language about equality as disadvantage may also arguably confine both federal and provincial legislative choices about entitlement to legal aid services in Canada, particularly where they fail to accord substantive equality on the basis of gender. In the context of Andrews, legal aid services must take account of substantive disadvantages for women, not merely whether women are similarly situated in relation to men with respect to gender neutral services.

Thus, both the Andrews decision and others relating to sex equality 
guarantees mandate legal aid services for men and women without discrimination. In this way, legal aid programmes must be assessed, not in terms of the gender-neutral language they use to describe entitlement to legal aid services, but in relation to the substantive outcome of the application of their criteria. Thus, the gender equality objectives of legal aid programmes must be tested in terms of outcomes and results, not just aspirations.

\section{RE-VISIONING ACCESS TO JUSTICE FOR WOMEN}

Effective strategies for gender equality require a re-assessment of ends as well as means. The paradigmatic liberal prescription equal opportunity is a necessary but never sufficient social objective. The ultimate goal is not simply to ensure women's full participation in organizations that wield social, economic, and political power; it is rather to change the nature of those organizations and the way power is distributed and exercised. Our priority should be to empower women as well as men to reshape the institutions that are shaping them. At issue is not simply equality between the sexes, but the quality of life for both of them. ${ }^{50}$

Rhode's assertion captures the difference between an analysis of gender equality in our current legal aid arrangements and visions of access to justice which promote substantive equality for men and women in the legal process. In her view, for example, such re-assessment means that concerns about individual intent in legal analysis should be 
replaced by a focus on institutional practices in relation to discrimination; thus, she has suggested that 'the law's approach to rape, sexual harassment and domestic violence must reach beyond the relatively rare circumstances in which an individual plaintiff comes forward with conclusive proof of injury' to one which focuses 'more critically on the cultural conditions that foster sexual abuse and on the law-enforcement practices that discourage redress'. ${ }^{51}$ Such restructuring might need to take seriously the identification of what legal aid services are appropriate for the victims of family violence (more often women and children) and how services should be organized to be most effective in meeting their needs. Thus, focusing our attention on legal aid services as an institutional resource for achieving equality, we may need to rethink the provision of legal aid services in family law matters, the need for student legal aid clinics which offer services to battered women but not to male batterers, and the appropriateness of a legal aid clinic providing services to women in family law matters. In each case, the real question is the extent to which such services contribute to institutional objectives of substantive equality. Or, as Rhode suggested, 'by broadening our aspirations to justice, we may come closer to attaining it'. ${ }^{52}$ 
* Osgoode Hall Law School, 4700 Keele Street, North York, Ontario, Canada M3J 1P3. The technical assistance of Hazel Pollack, and research assistance from Michael Gardner, Gaylene Schellenberg, and Lee Waldorf in my work on gender and legal aid, is warmly acknowledged. Funding provided by the Department of Justice, Canada, for part of this research project is also acknowledged; this paper, however, represents the views of the author and not the Department of Justice.

${ }^{1}$ Task Force on Gender Equality in the Legal Profession, Touchstonesfor change: Equality, Diversity and Accountability (Canadian Bar Association: 1993) at 211.

2 At the outset, the Task Force report stated unequivocally that it was a report about 'fundamental change'. See Task Force report, above n I, at 9. In addition, the Task Force explained its goal of fundamental change in terms of the increasing diversity of Canadian society:

'The Task Force has taken as its starting point the rhetorical question: should the legal profession continue to be a white male elitist institution or should it reflect the diversity of Canada? It is clear that the profession must become more representative of Canadian society. Women have gained entry to the profession in increasingly large numbers, but their entry has been marked by struggle rather than enthusiasm. This cold reception is accentuated for Women of Colour, Aboriginal women, women with disabilities and lesbians. True access to the profession will require a transformation in the profession itself'.

See Task Force report, above n I, at 23.

${ }^{3}$ See Task Force report, chs 4-10 and 12-13.

- The report reviewed constitutional and statutory protections against discrimination, and the jurisprudence of the Supreme Court of Canada interpreting these provisions, along with remedial actions. The report stated bluntly:

'The Task Force accepts as a basic premise that men and women should have an equal opportunity to enter and progress in the profession. It views discrimination on the basis of gender as equally repugnant to discrimination on the basis of race or religion. There is nothing controversial about this assertion. It is the law and must form part of the framework for change in the legal profession.' (emphasis added)

Task Force report, above n I, at 11-12.

5 Task Force report, above n !"at 17-19.

${ }^{6}$ See Task Force report, above n I, at ch. II.

${ }^{7}$ Task Force report, above n I, at 205.

${ }^{8}$ Ibid.

${ }^{9}$ See Task Force report, above n I, at 203-8.

${ }^{10}$ Task Force report, above n I, at 205.

${ }^{11}$ Michael Freeman, 'Towards a Critical Theory of Family Law' (1985) 38 Current Legal Problems 153, at 155. See also Pamela Symes, 'Property, Power and Dependence: Critical Family Law' (1987) 14Journal of Law and Society 1299; and Nikolas Rose, 'Beyond the Public/Private Division: Law, power and the Family' (1987) 14Joumal of Law and Society 61. 
${ }^{12}$ The Legal Aid Committee in Ontario reported in the Fall of 1993, for example, on projected shortfalls in legal aid funding and suggested measures for meeting these shortfalls. The suggestions included increasing the levies on members of the legal profession (now set at \$292 per year for those who do not participate in providing legal aid services); and amending the Law Society Act so as to require lawyers who control mixed trust accounts at the major banks to set up a joint mixed trust account with the Law Foundation of Ontario so that the funds could be invested at higher rates of return. These proposals and others were outlined in some detail in an interview with the Chair of the Law Society's Legal Aid Committee, Ms Fran Kiteley, reported in the Law Times (7 November 1993) at 7.

${ }^{13}$ See Legal Action Group, A Strategy for Justice (1992) at ch. 3. According to the author, 'although the number of matrimonial and family cases has grown over the last decade, these take up a decreasing proportion of civil legal aid certificates'. Ibid., at 33.

${ }^{14}$ Task Force report, above n 1, at 208.

${ }^{15}$ The Task Force report quoted with approval the comments of L'Heureux-Dube $\mathbf{J}$ in the decision of the Supreme Court of Canada in Mage v Mage (1992), 99 DLR (4th) 456, at 498 (quoting an earlier decision of the Quebec Court of Appeal), affirming the need to treat family law cases more equitably by comparison with other kinds of litigation:

'[S]o often the evidence [in family matters] is incomplete owing to the ignorance or incompetence of counsel or the inexperience or unreasonable expectations of the client! Or the evidence is cut short so as not to prolong the discussion (or make the judge impatient) when there is already an overloaded list of such cases to be heard! Or the evidence is truncated owing to a lack of interest or a failure to understand its full meaning!

It is significant that this type of carelessness occurs much less often in the fields of contract, insurance or tort, which are classified as 'civil law' as distinct from 'family law', yet the law should not be prepared to accept half-measures in either case. The outcome of a family lawproceeding iscertainly more dramatic. Lack ofincome is felt daily, and may affect the children's entire lives, aside from often working to the detriment of the person who though with adequate resources, deprives his family of what they need.

This, in my view, had to be said since such deficiencies are so often encountered in the entering of evidence in family law cases'.

See Task Force report, above n 1, at 212. For an interesting analysis of the family law decisions of L'Heureux-Dube $\mathbf{J}$, see also Marlene Cano, 'Claire L'Heureux-Dube et le droit de la famille: Juge innovateur? ... Innovatrice' (1991) 12 Queen's Quarterly 131.

${ }^{16}$ Although the report did not identify differences among different provincial legal aid schemes, it did confirm that fewer concerns were expressed in Quebec, a province which utilizes primarily a 'staff lawyer' model for delivering legal aid services. For some information about the cost of legal aid services in family law cases in Quebec some years ago, see Ministere de la Justice du Quebec,

'Evaluation of Legal Aid' (1983) and see M. J. Mossman, 'Toward a Comprehensive Legal Aid Program in Canada: Exploring the Issues' (1993) 4 WindsorJournal of Legal and Social Issues 1.

The report's positive comments about mediation and negotiation do not clearly reflect the continuing controversy in Canada about the appropriate use of alternate dispute resolution in family law. Just as in the United Kingdom, the use of mediation in family law has received serious criticism in Canada. For example, see (for the United Kingdom) Anne Bottomley, 'What is 
Happening to Family Law? A Feminist Critique of Conciliation' in Julia Brophy and Carol Smart (eds), Women-in- Law: Explorations in Law, Family and Sexuality (Routledge and Kegan Paul: 1985 ) at 162; and (for Canada) Martha Shaffer, 'Divorce Mediation: A Feminist Perspective' (1989) 46 University of Toronto Law Review 162; and Martha Bailey 'Unpacking the "Rational Alternative": A Critical Review of Family Mediation Movement Claims' (1989) 8 Canadian Journal of Family Law 61.

${ }^{17}$ Task Force report, above n 1, at 208-9, quoting from a submission received by the Task Force.

${ }^{18}$ See Task Force report, above $\mathrm{n} \mathrm{1,}$ at 213: Recommendation 11.3. The Task Force's recommendation reinforced an earlier recommendation of the Federal/Provincial/Territorial Working Group Report on Gender Bias in the Justice System. See also The Law Society of British Columbia, Gender Equality in the Justice System (The Law Society of British Columbia Gender Bias Committee: 1992).

${ }^{19}$ In Andrews v Law Society Of British Columbia [1989] 1 SCR 143, the Supreme Court of Canada established the approach to interpreting the guarantees of equality in section 15 of the Canadian Charter of Rights and Freedoms; according to the Task Force report, the approach in Andrews should be understood as a 'purposive' one, focusing on the redress of disadvantaged groups in society, having regard to the social, political and economic conditions. Thus, the Task Force concluded that 'the contextual approach was the "kiss of death" to the concept of formal equality'. Task Force report, above n 1, at 13.

${ }_{2}^{\circ}$ For an excellent comparison of Canadian and American jurisprudence on equality, see Lynn Smith, 'Adding a Third Dimension: The Canadian Approach to Constitutional Equality Guarantees' (1992) 55 Law and Contemporary Problems 212.

${ }^{21}$ See Jennie Abell, 'Women, Violence and the Criminal Law: "It's the Fundamentals of Being a Lawyer that are at Stake Here"' (1992) 17 Queen's Law journal 147.

22 The availability of legal aid services in different fora is one of the interesting features of Ontario's 'mixed' delivery system for legal aid services. Although the legal aid programme in Ontario relies primarily on the issuance of 'certificates' to members of the private Bar for legal aid services (as defined by the legislation and policies developed by the Ontario Legal Aid Plan), lawyers are also designated to provide 'duty counsel' services in some matters in designated courts; and there are over seventy community legal aid clinics with a mandate to provide legal aid services, primarily in areas other than criminal legal aid services and family law. There are also 'hybrid' student legal aid services in which law students at Ontario's six law schools offer legal aid services similar to those offered by the community legal aid clinics, but also limited services in the areas of family and criminal law. For further details about the 'mixed' system, see Mossman, above n 16 and Lightman and Mossman, 'Salary or Fee-for-Service in Delivering Legal Aid Services: Theory and Practice in Canada' (1984) 10 Queen's Law Journal 109. The history of legal aid in Canada is explored in Dieter Hoehne, Legal Aid in Canada (Edwin Mellen Press: 1989); for the history of legal aid in Ontario, see Mary Pat Reilly, 'The Origins and Development of Legal Aid in Ontario' (1988) 8 Windsor Yearbok of Access to Justice 81.

The conclusion that male clients charged with battering were not being denied legal advice and representation is supported by a letter from Dean Donald McRae, Dean of the law school at the 
University of Ottawa, to the local newspaper, the Ottawa Citizen, stating that the students' arrangements for providing legal aid services to women victims of violence, but not to male batterers, was consistent with the law of discrimination in Ontario:

'It is difficult to understand the vehement and at times almost hysterical attack made on this policy. Its practical effect is that a very small number of men who in the past might have been represented by students will now be represented by practising lawyers, and a significant number of women who have no alternative legal support will now receive representation. This is not discrimination. There is no denial of the right of any accused to the best possible defence available. There is no prejudging of the guilt of men charged with assault against women.

Acting on the conviction that violence against women is a serious problem, the Student Legal Aid Society is, in accordance with its mandate and in the best tradition of community legal aid programs in the province, seeking to make provision for a particular group whose needs are not adequately served by the existing system'.

See Abell, above n 21, at fn 14.

${ }^{23}$ See Abell, above n 21, at 150. For details of the complaint correspondence, see M.J. Mossman, '"Shoulder to Shoulder": Gender and Access to Justice' (1990) 10 Windsor Yearbook Of Access to Justice 351, at $360 \mathrm{ff}$.

The complaint to the Law Society alleged that the policy adopted by the student legal aid clinic violated 'the most sacred principles on which our justice system is based' and constituted discrimination on the basis of sex. According to Christine Boyle, the response of the Ottawa criminal defence Bar placed legal aid clinics in the position of having to explain (again!) 'that services which are tailored to women's needs only break one rule, the rule that the world must be organised to suit the needs of men'. See Christine Boyle, 'Commentary' (1990) 10 Windsor Yearbook of Access tojustice 376, at 379 .

${ }^{24}$ According to one lawyer opposed to the proposed women-only clinic, 'this is not a clinic that is devoted to women who are victims of physical or sexual assault' and 'a strong case could be made for it if it were offering services particular to women'. Such comments suggest acceptance of the idea of women-only services in principle, so long as they clearly relate to issues which are regarded as sex-specific. It is interesting that family law services for women, especially in the context of domestic violence, are not regarded as within this category. For further details, see DarylLynn Carlson, 'LSUC Turns Down "Discriminatory" Women's Clinic' (Law Times: 12 December $1993)$ at 5. See also the bluntly critical views of a feminist journalist about this decision: Michelle Landsberg, 'Lopsided Legal System Denies Justice to Wives' ( Toronto Star, 14 January 1994 and 15January 1994).

${ }^{25}$ Most recently, the student legal aid clinic at Osgoode Hall Law School has become embroiled in these issues in relation to its policy of representing women involved in domestic violence, and not males accused of battering. See Osgoode Hall Law School, Obiter Dicta (17 January 1994) at

I.News reports have also indicated that the Government has not abandoned interest in a women- only legal aid clinic; according to a recent report, the Attorney-General Marion Boyd recently told the Law Society that 'she hopes that a law clinic that would exclude men but focus entirely on the varied needs of female family law consumers can be developed for the province'. As she spoke, 'about 30 divorced or separated mothers marched and chanted outside 


\section{Osgoode Hall ...' Toronto Star (30 January 1994) at A4.}

Lynn Smith has suggested that the issue in such cases is not really the needs oflegal aid clients, but rather the 'backlash' against legal gains made by women as they have become a critical mass in law schools and in the legal profession in Canada in the past two decades. Inthe Ottawa student clinic situation, she suggested that one could observe 'one of the classic features of backlash the waving of banners with slogans that have very little to do with the issues at stake'. See Lynn Smith, 'Commentary' (1990) 10 Windsor Yearbook of Access tojustice 382, at 383.

${ }^{26}$ Above n 21.

27 Abell, above n 21 at 152-3. See also the Dean's letter to the press, above n 22 .

28 Abell, above n 21, at 154. See, for example, Linda MacLeod, Battered but not Beaten . ..Preventing Wife Battering in Canada (Canadian Advisory Council on the Status of Women: 1987); Mary-Lou Fassel, 'Wife Assault and the Criminal Justice System: Can Women Find Fairness in a System Built for Men?' (1990) 8 Vrs-a-Vrs \#1, 1; Laura Crites, 'A Judicial Guide to Understanding Wife Abuse' (1985) 24 Judges journal 5; and Education Wife Assault, 'Violence in Canadian Society' (1987) 7juristat \#2, 13.

${ }^{29}$ Abell, above $\mathrm{n} \mathrm{21}$, at 154. In the hearing before the Law Society, the Women's Legal Education and Action Fund presented a brief, arguing that effective legal aid services for battered women required the adoption of a policy, such as that of the Ottawa student legal aid clinic, which recognized both their special needs and the necessary design of legal services responsive to their needs:

'[The policy] provides a service that is not otherwise available to a disadvantaged group without in any way jeopardizing the relatively significant societal resources already currently available to those accused of such violence. The clinic would be limited in its ability to accomplish its equality-promoting objectives if it did represent such male accuseds. It would be forced to reject particular women as clients because of individual cases of conflict of interest. It would not be able to dedicate its resources to developing a more comprehensive consistent service to a disadvantaged group. It would risk undermining that service by the temptation to put forward the type of defence to charges that feeds into myths about violence, frequently made part of a 'complete' defence'.

See letter of support filed by Helena Orton on behalf of the Women's Legal Education and Action Fund (LEAF), 22 November 1990, at 2; as quoted in Mossman, above n 23, at 362.

${ }^{30}$ Deborah Rhode, justice and Gender: Sex Discrimination and the Law (Harvard University Press: 1989) at 82. For another critique of justice and the family, see Susan Moller Okin, justice, Gender

and the Family (Basic Books: 1989).

${ }^{31}$ Rhode, above n 30, at 321. In the American context, Lynne Hecht Schafran has suggested that the process of investigating gender bias in the law is a 'transformative experience'. See Schafran, 'Gender and Justice: Florida and the Nation' (1990) 42 Florida Law R.eview 181, especially at $202 \mathrm{ff}$.

${ }^{32}$ For a detailed analysis of categorical entitlement, both in relation to mandatory and discretionary services, and the relationship of categorical entitlement to eligibility guidelines, see Mossman, above n 16.

\footnotetext{
${ }^{33}$ For an interesting discussion about legal categories, see Regina Craycar and Jenny Morgan,
} 
The Hidden Gender of Law (Federation Press: 1990) at $3 \mathrm{ff}$. As they suggested:

'Legal practitioners have always known that people's lives did not readily fit into legal categories, but this has not often been reflected in a legal system which fragments its treatment of people's problems into categories ... For women, these artificial classifications are especially problematic

,

${ }^{34}$ See Legal Aid Bulletin (No 76,June 1992). See also details about the limited availability of legal aid services in civil law matters in the province of New Brunswick in DPA Group Inc, Evaluation of Legal Aid inNew Brunswick (1986).

${ }^{35}$ For an overview of research about 'hidden' gender bias in law and legal research, see Lynn Smith, 'What is Feminist Legal Research?' in W. Tomm (ed), The Effects of Feminist Approaches on Research Methodologies (Wilfrid Laurier Press: 1988) 71.

36 For an analysis of women and poverty, and the relationship to family law, see Erika Abner,

M.J. Mossman and Elizabeth Pickett, "' A Matter of Simple Justice": Assessing the Report of the Ra:al Commission on the Status of Women in Canada' (1990) 22 Ottawa Law Review 573.

There is some evidence that legal services are generally utilized more frequently by men than by women in Canada. In a 1979 study, McKie and Reed concluded that women did not use the civil courts as frequently as men; see C. McKie and P. Reed, Women in the Civil Courts (Department of Justice: 1979). Even in the context of criminal courts, women are represented significantly less often than men; see E. Adelberg, A Forgotten Minority: Women in Conflict with the Law (Can Assoc of Elizabeth Fry Societies: 1985). However, these studies may not reflect the needs for legal services (eg legal aid services) for poor women.

${ }^{37}$ Martha Fineman, in Fineman and Thomadsen (eds), At the Boundaries of Law: Feminism and Legal Theory (Routledge: 1991) at xiii. See also Martha Fineman, 'Challenging Law, Establishing Differences: The Future of Feminist Legal Scholarship' (1990) 42 Florida Law Review 25.

${ }^{38}$ Richard Abel, 'Law Without Politics: Legal Aid Under Advanced Capitalism' (1985) 32 UCLA Law Review 474, at 476. See also Carrie Menkel-Meadow, 'Legal Aid in the United States: The Professionalization and Politicization of Legal Services in the 1980s' (1984) 22 Osgoode Hall Law Journal 29.

${ }^{39}$ For an excellent account of the public/private dichotomy in law, see Margaret Thornton, 'The Public/Private Dichotomy: Gendered and Discriminatory' (1991) IS Journal of Law and Sociery 448.

"० See Ministry of the Attorney General, Report of thejoint Committee on Legal Aid (1965) at 65.

${ }^{41}$ See, for example, Legal Aid Cost-Sharing Agreement, Canada and Ontario (1987-88) Part I and Schedule B. See also 'Legal Aid in Criminal Cases' in Study Team Report to the Task Force on Program Review, Improved Program Delivery: justice System (Government of Canada: 1986). Some funding for legal aid in civil matters has been available pursuant to the federal legislation, the Canada Assistance Plan; however, in recent years, the federal Government has unilaterally altered the terms of the funding arrangements pursuant to this legislation. For an example of the impact of the cost-sharing agreements on provincial legal aid plans (and the consequential elimination of legal aid services in civil law (including family law) matters), see New Brunswick Evaluation, above n 34. 
${ }^{42}$ See Adelberg, above $\mathrm{n} 36$, for current Canadian statistics about criminal activities of men and women. Some interesting questions about women in the criminal justice system are also raised in F. Heidensohn, 'Models of Justice: Portia or Persephone? Some Thoughts on Equality, Fairness and Gender in the Field of Criminal Justice' (1986) 14 International Journal of the Sociology of Law 287.

${ }^{43}$ See Shelley Gavigan, 'Women's Crime: New Perspectives and Old Theories' in E. Adelberg and C. Currie (eds), Too Few to Count: Canadian Women in Conflict with the Law (Press Gang Publishers: 1987) 53. See also M. Eaton, 'Documenting the Defendant: Placing Women in Social Inquiry Reports' in J. Brophy and C. Smart (eds), Women in Law: Explorations in Law, Family and Sexuality (Routlege and Kegan Paul: 1985).

${ }^{44}$ See, for example, Wendy Williams, 'The Equality Crisis: Some Reflections on Culture, Courts, and Feminism' (1982) 7 Women's Rights Law Reporter 182; and Williams, 'American Equality Jurisprudence' in S. Martin and K. Mahoney (eds), Equality andjudicial Neutrality (Carswell: 1987) 115.

${ }^{45}$ For example, see Elizabeth Wolgast, Equality and the Rights of Women (Cornell University Press: 1980) who argued for equal rights and also for special rights for women; the latter were especially important in relation to pregnancy and breast-feeding. See also Ann Scales, 'Towards a Feminist Jurisprudence' (1981) 56 Indiana Law Journal 375.

${ }^{46}$ (1989) 59 DLR (4th) 321.

47 (1989) 59 DLR (4th) 352.

${ }^{48}$ (1987) 76 NR 161.

49 (1990) 108 NR 321.

fj) Deborah Rhode, above n 30, at 320.

${ }^{51}$ Ibid.

${ }^{5}$ i Rhode, aboven 30 , at 321. 